\title{
KONDISI SUPERVISI PENDIDIKAN YANG SEHARUSNYA TERJADI
}

\section{NURASTATI}

\author{
Nurastati04@gmail.com
}

\begin{abstract}
ABSTRAK
Supervisi dalam dunia pendidikan sangat penting dilaksanakan karena berpengaruh terhadap kinerja guru pada hasil pembelajaran, dengan demikian pelaksanaan supervisi dapat berjalan dengan baik maka perlu diketahui apa dan bagaimana supervisi suatu pendidikan. Supervisi akademik merupakan suatu hal yang harus diketahui terlebih dahulu oleh seorang kepala sekolah, karena seorang kepala sekolah dia akan menjalankan suatu suprvisi atau disebut sebagai seorang supervisor dalam pelaksanaan supervisi. Kepala sekolah harus mampu mengelola kinerja guru di sekolahnya. Dalam menjalankan tanggung jawabnya mengelola kinerja, kepala sekolah berkontribusi pada peningkta kierja organisasi secara keseluruhan sebagai upaya mendapatkan hasil yang lebih baik. Supervisi pendidikan yang dilakukan oleh kepala sekolah berpengaruh positif dan signifikan terhadap perubahan kinerja guru. Kinerja guru akan dapat ditingkatkan bila supervisi pendidikan kepala sekolah dalam bentuk kepemimpinn dan pengawasan ditingkatkan. Keterlibatan seluruh komponen pendidikan guru (guru, kepala sekolah, masyarakat, komite sekolah, dewan pendidikan dan institusi)melalui perencanaan yang baik dan merealisasikan suatu program pendidikan yang diluncurkan.
\end{abstract}

Kata Kunci : Supervisi Pendidikan; Kinerja Guru

\section{LATAR BELAKANG}

Menurut UU RI No. 20 Tahun 2003 tentang Sistem Pendidikan Nasional mengamanatkan bahwa Pendidikan merupakan usaha sadar dan terencana untuk mewujudkan suasana belajar dan proses pembelajaran agar peserta didik secara aktif mengembangkan potensi dirinya untuk memiliki kekuatan spiritual keagamaan, pengendalian diri, masyarakat, bangsa daan negara. Ermi Sola mengemukakan (Sola, 2018) Dalam hal ini, guru merupakan tokoh utama tercapai pembelajaran yang bermakna. Kehadiran guru dalam kelas dengan semua aktifitas yang melibatkan dirinya dan semua peserta didik akan mewarnai keberhasilan maupum kegagalan proses belajar mengajar. Meningkatkan kualitas pendidikan bukan perkara yang mudah, diperlukan adanya keterkaitan yang erat dari berbagai faktor dengan memperhatikan kondisi masa lalu, masa kini dan masa depan yang sulit diramalkan. Ketidapahaman dalam memperkirakan kebutuhan masa depan menimbulkan sulitnya memecahkan berbagai masalah pendidikan, baik yang menyangkut kualitas, relevansi, efesiensi, maupun efektifitas pendidikan.

Istilah supervisi baru muncul kurang lebih tiga dasawarsa terakhir ini. Seorang supervisor membina peningkatan mutu akademik yang berhubungan dengan usaha-usaha menciptakan kondisi belajar yang lebih baik berupa aspek akademis, bukan masalah fisik material semata. Ketika supervisi dihadapkan pada kinerja dan pengawasan mutu pendidikan 
oleh pengawas satuan pendidikan, tentu memiliki misi yang berbeda dengan supervisi oleh kepala sekolah.

Menurut Hanafiah (Hanafiah, 2017)Hal ini bertujuan untuk memberikan pelayanan kepada kepala sekolah dalam mengembangkan mutu kelembagaan pendidikan memfasilitasi kepala sekolah agar dapat melakukan pengelolaan kelembagaan secara efektif dan efisien.

Bagaimana seharusnya pendidikan itu

1. Pendidian Seharusnya Menyenangkan

Meski proses pembelajaran dituntut untuk mencapai target-target tertentu, kita tidak boleh terjebak dalam lingkaran kecil dan mengorbankan waktu perkembangan anak yang begitu berharga dengan pressure-pressure yang justru menjadikan masa belajar menjadi momen-momen menyakitkan yang tumbuh menjadi kenangan pahit untuk diingat saat mereka dewasa.

2. Pendidikan seharusnya lebih mementingkan sikap positif

Diantara Tiga aspek pendidikan, penanaman sikap dan nilai-nilai seharusnya lebih diutamakan. IMHO keterampilan dan pengetahuan hanya bisa dicapai secara optimal dengan sikap positif. Sikap rendah hati tidak merasa paling pintar mendorong setiap oprang mawas diri akan sesuatu yang perlu diperbaiki. Sikap saling suka suka menolong bisa membangun sebuah lingkungan yang sangat kondusif untuk belajar. sikap sopan bisa menciptakan iklim yang baik untuk proses pembelajaran. Sikap obyektif akan kekurangan mendorong orang menyadari bahwa ia harus berupaya lebih keras dari yang lainnya.

3. Pendidikan seharusnya murah di mata sumber ilmu, mahal dimata pencari ilmu.

Kita berhutang banyak pada para ilmuwan, apa yang kita kuasai tidak pernah murni dari pemikiran, penelitian mandiri. peradaban dibangun dari proses regenerasi pengetahuan. Hal yang tebaik untuk membayarnya adalah dengan menyebarkan pada semua orang yang mau belajar tanpa terkecuali, tanpa dihalangi keterbatasan usia, kemampuan finansial dll.

4. Institusi pendidikan seharusnya berusaha menjadi pusat transformasi sekaligus pemeliharaan nilai, sikap, pengetahuan dll.

sekolah harus memiliki standar nilai yang lebih tinggi dari lingkungan disekitarnya. Harus ada filter yang memastikan sekolah senantiasa steril dari penyakit-penyakit sosial yang mungkin berjangkit diluar. Dalam situasi inilah anak didik belajar membedakan yang baik dan yang buruk, yang benar dan yang salah, sehingga lahir generasi yang memiliki standar moral etik, logik, estitik tinggi dan siap mengambil peran dalam dunia real.

Kondisi Supervsi Pendidikan Yang Terjadi yaitu ada yang sesuai diharapkan dan ada yang tidak sesuai diharapkan.

\section{RUMUSAN MASALAH}

(1) Apa pengertian dari Supervisi Pendidikan;(2) Bagaimanakah seharusnya pendidikan itu;(3) Bagaimanakah alternatif pemecahan permasalahan pelaksanaan supervisi pendidian disekolah. 


\section{TUJUAN}

Untuk mempelajari bagaimana kita sebagai seorang guru bisa memberikan proses belajar mengajar yang baik di berikan pada murid dan bisa mencapai tujuan pembelajara yang diharapkan.

\section{PEMBAHASAN}

Menurut sabandi(Sabandi, 2013) supervisor memegang peranan penting dalam meningkatkan kualitas guru agar dapat melaksanakan pembelajaran yang lebih berkualitas. Jabatan supervisor di sekolah meliputi kepala sekolah dan pengawas. Supervisi yang dilakukan oleh kepala sekolah diatur dalam Permen Diknas Nomor 13 Tahun 2017 tentang Standar Kepala Sekolah/Madrasah. Dimensi kompetensi supervisi kepala sekolah yang meliputi : (1) Merencanakan program supervisi akademik dakam rangka peningkatan profesionalisme guru, (2) Melakasanakan supervisi akademik terhadap guru dengan menggunuakan pendekatan dan teknik supervisi yang tepat, (3) Menindak lanjuti hasil supervisi akademik terhadap guru dalam rangka peningkatan pofesinalisme guru. Disamping itu , supervisi yang dilakukan oleh pengawas diatur dalam Permen Diknas Nomor 12 Tahun 2007 tentang Standar Pengawas Sekolah /Madrasah. Dimensi kompetensi pengawassekolah/madrasah meliputi : (1) Kompetensi kepribadian, (2) Kompetensi supervisi manajerial, (3) kompetensi supervisi akademik, (4) Kompetensi evaluasi pendidikan, (5) Kompetensipenelitian pengembangan, (6) Kompetensial.

Supevisi Pendidikan adalah suatu proses pemberian layanan dalam misi dan visi untuk mencapa tujuan pendidikan melalui peningkatan kinerja guru baik secara individual maupun kelompok.

Permasalahan dari pelaksanaan Supervisi Pendidikan di sekolah dalam melaksanakan supervisi kepala sekolah pasti menghadapi kendala-kendala. Hal ini sesuai dengan yang telah disampaikan oleh Direktorat Tenaga Kependidikan Dirjen Peningkatan Mutu Pendidik dan Tenaga Kependidikan Departemen Pendidikan Nasional (2007), "Para kepala sekolah baik suka maupun tidak suka harus siap menghadapi problema dan kendala dalam melaksanakan supervisi pendidikan".

1. Kompleksitas tugas manajerial seorang kepala sekolah.

Program kegiatan supervisi pendidikan tidak dapat dilakukan oleh kepala sekolah seorang diri. Kompleksitas tugas manajerial kepala sekolah mengakibatkan seorang kepala sekolah tidak dapat menangani sendiri pelaksanaan supervisi pendidikan, khususnya supervisi yang lebih menekankan pada aspek pembelajaran.

2. Kurangnya persiapan dari guru yang disupervisi.

Meskipun pelaksanaan supervisi pendidikan dilakukan dengan pemberitahuan terlebih dahulu kepada guru yang akan mendapat supervisi, masih saja para guru yang akan disupervisi belum mempersiapkan diri secara matang.

3. Unsur subjektifitas guru supervisor dirasa masih tinggi.

Unsur subjektifitas dari supervisor yang ditunjuk oleh kepala sekolah dirasa masih tinggi. Keadaan ini terjadi dikarenakan kegiatan supervisi pendidikan tidak dilakukan sendiri secara langsung oleh kepala sekolah, tapi oleh guru-guru yang dianggap telah senior oleh 
kepala sekolah. Dimana masing-masing guru tersebut memiliki kepribadian yang berbedabeda dan prinsip supervisi maupun teknik supervisi yang saling berbeda pula.

4. Sering terjadi pergantian kepala sekolah

Terjadinya pergantian kepala sekolah mengakibatkan jalannya pelaksanaan supervisi pendidikan menjadi tesendat-sendat, kurang lancar, dan dinilai kurang rutin/ kontinyu.

5. Sarana dan prasarana yang terbatas

setiap proses belajar mengajar yang berhubungan dengan masalah sarana dan prasarana, seorang guru pasti merasakan ketidak nyamanan dalam menyampaikan materi pelajaran. Karena sarana dan prasarana merupakan salah satu faktor utama lancarnya pelaksanaan supervisi pendidikan dalam meningkatkan profesionalisme guru.

6. Kurangnya disiplin guru

Masalah yang menyangkut faktor disiplin. hal ini sering dilakukan oleh beberapa tenaga pengajar terutama disiplin waktu hal ini menimbulkan kelas menjadi tidak kondusif sehingga siswa tidak tau apa yang harus dilakukan selain bermain di dalam kelas sambil menunggu guru yang memiliki jadwal pada hari itu ia akan datang atau karena tidak belum ada kejelasan.

7. Masih kurangnya pengetahuan guru tentang pengelolaan proses belajar mengajar yang efektif seorang guru dintuntut agar mampu melaksanakan belajar mengajar yang efektif sehingga suasana kelas menjadi kondusif.

Alternatif pemecahan permasalahan pelaksanaan Supervisi Pendidikan di Sekolah

Supervisi nampaknya menjadi penentu yang utama untuk memutuskan kurikulum, menyeleksi pola-pola organisasi sekolah, fasilitas belajar, dan menilai proses pendidikan secara keseluruhan. Oleh karena itu diperlukan solusi yang tepat agar apa yang menjadi tujuan utama dari pelaksanaan supervisi pendidikan oleh kepala sekolah dalam penerapan kurikulum di sekolah dapat sepenuhnya tercapai.

Kepala sekolah selaku supervisor pendidikan yang memiliki otoritas tertinggi di sekolah harus mengupayakan beberapa cara dalam mengatasi kendala-kendala dalam pelaksanaan supervisi, antara lain:

1. Dilakukan pendelegasian wewenang oleh kepala sekolah kepada guru-guru senior.

Pelaksanaan supervisi terutama pada aspek pembelajaran tidak dapat dilakukan seorang diri oleh kepala sekolah tanpa bantuan dari orang lain. Oleh karena itu, kepala sekolah yang notabene pimpinan sekolah yang memiliki otoritas tertinggi memiliki keleluasaan untuk melakukan delegasi wewenang. Kegiatan supervisi pada aspek pembelajaran dapat dilimpahkan kepada guru yang dianggap senior berdasarkan kriteria-kriteria tertentu. Kriteria guru senior yang dipilih adalah dilihat dari masa kerja, prestasi kerja, kompetensi, dan kualifikasinya, misal guru yang bergelar S2. Kegiatan supervisi oleh guru supervisor terhadap rekannya sering disebut dengan pembimbingan teman sejawat dalam kegiatan belajar mengajar.

2. Pemberian motivasi kepada para guru akan pentingnya supervisi pendidikan.

Kurangnya persiapan dari guru dalam pelaksanaan supervisi, lebih diakibatkan karena kuranganya motivasi dari dalam guru sendiri akan pentingnya supervisi pendidikan. Motivasi yang minim itu juga disebabkan kerena anggapan yang telah melekat dalam diri guru bahwa 
supervisi hanyalah kegiatan yang semata-mata untuk mencari-cari kesalahan. Pemberian motivasi dapat dilakukan melalui beberapa cara diantaranya dengan menyelipkan pengarahan atau motivasi pada saat rapat guru, lokakarya, atau bahkan secara langsung dengan individunya.

3. Pembinaan oleh kepala sekolah kepada guru-guru senior yang ditunjuk sebagai supervisor dan membentuk tim penilai supervisi.

Kepala sekolah perlu memberi motivasi maupun pengarahan kepada para guru supervisor yang isinya mengenai perlunya menerapkan prinsip-prinsip supervisi pendidikan dan pembentukan tim penilai supervisi yang terdiri dari 2 (dua) atau 3 (tiga) orang yang tujuannya tidak lain adalah untuk menetralisir unsur subjektifitas yang terjadi oleh guru yang berperan supervisor.

4. Dilakukan koordinasi secara intens kepada seluruh elemen sekolah.

Pergantian kepala sekolah sebanyak empat kali dalam lima tahun menjadi kendala yang cukup fatal bagi pengelolaan dan kemajuan sekolah. Hal tersebut berdampak pula pada rutinitas kegiatan supervisi pendidikan. Upaya dari kepala sekolah untuk mensikapi keadaan tersebut adalah dengan melakukan koordinasi secara intensif kepada seluruh elemen sekolah, termasuk koordinasi yang baik antara guru supervisor dengan guru yang akan mendapat supervisi.

5. Mengupayakan sarana dan prasarana yang memadai

Sarana dan prasarana merupakan sesuatu yang penting disemua tempat kegiatan belajar mengajar, karena itu, dalam rangka mensukseskan program pengajaran yang efektif tidak terlepas dari sarana dan prasarana yang memadai. seorang guru akan lebih semangat dengan situasi dan kondisi fasilitas sarana dan prasarana yang sudah lengkap. Sarana dan prasarana adalah suatu perlengkapan/ peralatan yang harus dimiliki oleh setiap sekolah pada umumnya. sedangkan prasarana mengikuti sarana.

6. Menerapkan disiplin terhadap tata tertib guru

Kepala sekolah harus mengingatkan kepada semua tenaga pengajarnya untuk melakukan kedisiplinan, misalnya agar menjalankan aturan-aturan sebagai berikut:

1) Guru harus mengisi daftar hadir yang sudah disediakan

2) Guru harus berpakain rapi sebagaimana layaknya seorang guru

3) Guru harus bersipat jujur, adil, terbuka dan demokratis

4) Guru harus membuat perangkat pembelajarn yang telah ditentukan oleh kepala sekolah

5) Guru harus menjaga kode etik guru indonesia

6) Guru harus menjaga nama baik sekolah

7) Guru harus taat pada aturan sekolah yang berlaku

8) Apabila kehadiran guru kurang dari $60 \%$ maka akan dikenakan sanksi.

7. Mengadakan evaluasi ketenagaan.

Evaluasi merupakan salah satu faktor yang mampu memberikan motivasi dan dorongan kepada guru agar lebih baik dan selalu meningkatkan perkembangan kemampuannya. disisi lain evaluasi ialah mserangkaian kegiatan yang dimana membuat para guru terkadang gelisah, guru yang seperti ini biasanya guru yang tertutup atau kurang humor/ pendiam. Adapun yang 
harus dilakukan kepala Sekolah adalah mendekatinya. kaitannya dengan upaya yang harus dilakukan kepala madarsah ialah evaluasi ketenagaan dalam menghadapi kendala dalam pelaksanaan supervisi pendidikan.

\section{KESIMPULAN}

Beberapa permasalahan dalam pelaksanan supervise di sekolah diantaranya:

1. Kompleksitas tugas manajerial seorang kepala sekolah

2. Kurangnya persiapan dari guru yang disupervisi

3. Unsur subjektifitas dirasa masih tinggi

4. Sering dilakukan pergantian kepala sekolah

5. Sarana dan prasarana yang terbatas

6. Kurangnya disiplin guru

7. Masih kurangnya pengetahuan guru tentang pengelolaan proses belajar mengajar yang efektif.

Sedangkan alternatif untuk mengatasi permasalahan tersebut antara lain:

1. Dilakukan pendelegasian wewenang oleh kepala sekolah kepada guru-guru senior

2. Pemberian motivasi kepada para guru akan pentingnya supervisi pendidikan

3. Dilakukan pembinaan oleh kepala sekolah kepada guru-guru senior yang ditunjuk sebagai supervisor dan membentuk tim penilai supervise

4. Dilakukan koordinasi secara intens kepada seluruh elemen sekolah

5. Mengupayakan sarana dan prasarana yang memadai

6. Menerapkan disiplin terhadap tata tertib guru

7. Mengadakan evaluasi ketenagaan.

\section{SARAN}

Masih banyak kesalahan dan kekeliruan dalam penyusunan Artikel ini. Penulis mengharapkan kritik dan sarana sebagai masukan,untuk perbaikan dimasa mendatang.

\section{REFERENSI}

Hanafiah, M. A. (2017). SUPERVISI DALAM ADMINISTRASI PENDIDIKAN Muhammad Ali Hanafiah. 14(1), 21-27.

Sabandi, A. (2013). SUPERVISI PENDIDIKAN UNTUK PENGEMBANGAN PROFESIONALITAS GURU BERKELANJUTAN. Pedagogi ,Jurnal Ilmiah Ilmu Pendidikan, 13(2), 1-9. Retrieved from http://ejournal.unp.ac.id/index.php/pedagogi/article/view/4275/3345

Sola, E. (2018). Ada apa dengan supervisi pendidikan? II(36), 130-140. 